\title{
A. Айтбаева
}

Пограничная академия КНБ Республики Казахстан, Алматы, Казахстан Автор-корреспондент: Айтбаева A., ardak3110@mail.ru

\section{ЦЕННОСТНЫЕ АСПЕКТЫ ЭКОЛОГИЧЕСКОГО ЗНАНИЯ}

Аннотация. В статье обсуждается вопрос о ценности экологического знания. Определяется специфика этого знания по сравнению с естественно-научным, общественным и техническим знанием. В то же время отмечается неоднородность экологического знания. С одной стороны, существует биологическая экология. Это - всецело естественнонаучная дисциплина. А экология человека, социальная экология и глобальная экология - это науки иного порядка. В них сочетаются элементы естественнонаучного знания (это знание о реальной экологической ситуации как таковой), социогуманитарного и даже технического знания. В статье анализируется, прежде всего, знание, вырабатываемое экологией человека и социальной экологией. Анализируется проблема «наука и ценности» и делается вывод, что ценностно нейтрального научного знания не бывает. Применительно к экологическому знанию проводится различение его абсолютной и относительной ценности (речь идёт об экологии человека, социальной и глобальной экологии). Абсолютная ценность экологического знания - это ценность его как такового. В нынешней экологической ситуации оно абсолютно необходимо, без него невозможно человечеству справиться с этой ситуацией. Оно поэтому и обладает статусом абсолютной ценности для человечества. Что же касается всякий раз конкретного экологического знания, то оно, будучи всякий раз относительным, обладает относительной ценностью.

Ключевые слова: экологическое знание, биологическая экология, экология человека, социальная экология, ценность, научная ценность, ценность экологического знания.

\section{Экологиялық білімнің құндылықтылық аспектілері}

\section{А. Айтбаева}

Қазақ̆стан Республикасы ҰҚК Шекара академиясы, Алматы, Қазақстан

Аннотация. Мақалада экологиялық білімнің құндылығы туралы айтылады. Бұл білімнің ерекшелігі жаратылыстану, әлеуметтік және техникалық білімдермен салыстырғанда анықталады. Сонымен бірге экологиялық білімнің біртектілігі атап өтіледі. Бір жағынан, биологиялық экология бар. Бұл толығымен жаратылыстану пәні. Бірақ адам экологиясы, әлеуметтік экология және ғаламдық экология басқа тәртіптегі ғылымдар. Олар жаратылыстану элементтерін (бұл нақты экологиялық жағдай туралы білім), әлеуметтік-гуманитарлық және тіпті техникалық білімдерді біріктіреді. Мақалада ең алдымен, адам экологиясы мен әлеуметтік экологиясы қалыптастыратын білім талданады. «Ғылым мен құндылықтар» проблема- 
сы талданып, құндылық бейтарап ғылыми білім жоқ деген тұжырым жасалады. Экологиялық білімге қатысты оның абсолютті және салыстырмалы мәнін ажыратады (адам экологиясы, әлеуметтік және ғаламдық экология туралы). Экологиялық білімнің абсолюттік мәні - оның мәні. Қазіргі экологиялық жағдайда бұл өте қажет, өйткені онсыз адамзат үшін бұл жағдайды жеңу мүмкін емес. Сондықтан ол адамзат үшін абсолютті құндылық мәртебесіне ие. Әрқашан нақты экологиялық білімге келетін болсақ, ол әр уақытта салыстырмалы бола отырып, салыстырмалы мәнге ие болады.

Түйін сөздер: экологиялық білім, биологиялық экология, адам экологиясы, әлеуметтік экология, экологиялық білімнің құндылығы, ғылыми құндылығы, құндылығы.

\section{Value Aspects of Ecological Knowledge}

\section{A. Aitbayeva \\ Border academy of National Security Committee of the Republic of Kazakhstan, Almaty, Kazakhstan}

Abstract. The article discusses the value of environmental knowledge. The specificity of this knowledge is determined in comparison with natural science, social and technical knowledge. At the same time, the heterogeneity of ecological knowledge is noted. On the one hand, there is biological ecology. It is an entirely natural science discipline. But human ecology, social ecology and global ecology are sciences of a different order. They combine elements of natural science (this is knowledge about the real ecological situation as such), socio-humanitarian and even technical knowledge. The article analyzes, first of all, the knowledge generated by human ecology and social ecology. The problem of "science and values" is analyzed and the conclusion is made that there is no value-neutral scientific knowledge. With regard to ecological knowledge, a distinction is made between its absolute and relative value (we are talking about human ecology, social and global ecology). The absolute value of ecological knowledge is its value as such. In the current ecological situation, it is absolutely necessary, because without it is impossible for humanity to cope with this situation. Therefore, it has the status of absolute value for humanity. As for concrete ecological knowledge every time, it, being relative every time, has a relative value.

Key words: Ecological Knowledge, Biological Ecology, Human Ecology, Social Ecology, Value, Scientific Value, Value of Ecological Knowledge.

\section{Введение}

Уже XX век вошёл в историю как век разнообразных кризисов, важнейшим среди которых является экологический. Наступивший XXI лишь обострил их. Всё увеличивающееся в темпах развитие промышленности, как мирной, так и военной, появление химических, биологических, ядерных и иных средств массового уничтожения человечества, их применение 
и даже испытание и хранение, загрязнение отходами промышленности и индустриализированного сельского хозяйства почвы, водного и воздушного бассейнов обернулось для человека, творца всего этого, угрозой не только его деградации (что видно уже сегодня), но и его полного исчезновения с лица планеты вместе с исчезновением биосферы.

Особая экологическая судьба выпала на долю Казахстана и его населения. Территория бывшей союзной республики была выбрана в качестве полигона для испытания смертоносного оружия. В 1953 г. безо всякого предупреждения населения был произведён испытательный взрыв первой в мире водородной бомбы. Причём взрыв был произведён наземным способом. Позже был построен космодром «Байконур», деятельность которого также оказывала и продолжает оказывать отрицательное влияние на биосферу аридной зоны и на здоровье людей.

Все эти процессы, происходящие в мире, обострили внимание к так называемым глобальным проблемам, среди которых экологические проблемы занимают одно из приоритетных мест. Действительное решение всех этих проблем, конечно, - дело практики. Но практика должна опираться на науку, в частности - на экологию как науку. В этой связи у знания, вырабатываемого в этой науке, повышается его статус и значимость, повышается его ценность. Исследование ценностных аспектов экологического знания и представляется сегодня актуальным.

Особенность авторского видения проблемы состоит в том, что, вопервых, необходимо чётче, чем это обстоит в соответствующей литературе, проводить разграничение экологии человека, социальной экологии и глобальной экологии от экологии естественнонаучной; во-вторых, необходимо избавляться от антропо-центристского подхода, господствующего в экологических исследованиях; в-третьих, в отличие от прочих авторов в статье проводится различение абсолютных и относительных ценностей экологического знания в экологии человека, социальной экологии и в глобальной экологии.

\section{Методология}

В статье применены методы, получившие свою известность и надёжность. Это, прежде всего, системный метод, принцип целостности и некоторые другие. Системный метод и принцип целостности позволили охватить экологические знания как некую целостную систему в её внутренних взаимосвязях, а принцип конкретности позволил определить ценностные аспекты каждого из видов экологического знания. 


\section{Статус экологии как науки}

По своим социальным функциям науки делятся на фундаментальные и прикладные. По предметам они традиционно разделялись на естественные и общественные. В XX-м веке к ним прибавились технические науки. Экология заявила о себе первоначально как естественная наука, как раздел биологии. Эта, биологическая экология, прошла путь развития и продолжает его, оставаясь сама собой, т.е. наукой естественной. Но в XX в. понятие экологии значительно расширилось. В предмет данной науки вошли человек и общество. Правда, биологическая экология с того времени, когда было выработано понятие биосферы, тоже включила в состав своего предмета человека и общество. Но она включила их лишь в их естественном, природном измерении: человека - как представителя одного из видов фауны, а обществ как специфическую популяцию. Биологическая экология абстрагируется от социокультурного измерения человека и общества, которые как раз и характеризуют его сущность.

Экология человека, социальная и глобальная экология принимают человека уже как социальное существо. А.Н. Кочергин, Ю.Г. Марков и Н.Г. Васильев пишут [1, с. 3 - 4], имея в виду социальную экологию: «Процесс формирования новой области знания далеко не традиционен. Он осуществляется особыми путями, отличными от путей возникновения таких дисциплин, как физика, химия, биология. Социальную экологию вряд ли правомерно рассматривать в рамках обычного дисциплинарного знания, или даже как «стыковую» дисциплину типа физической химии, биофизики или биохимии. ...Социальная экология - это не просто «стык» между социологией и экологией, а гораздо более сложное образование, в котором участвуют естественные, обществен: и технические дисциплины». Это, безусловно, накладывает свой специфический отпечаток на характере получаемого надбиологической, в данном случае социальной, экологией знания. И авторы пишут: «Социально-экологическое знание в явной форме выражает тенденции интеграции научного знания, характерные особенности междисциплинарного взаимодействия наук» [1, с. 4]. То же, в принципе, можно сказать и об экологии человека. Что касается глобальной экологии, то, очевидно, в ней взаимодействуют только естественные и общественные дисциплины, а место технических наук занимает философия. Разумеется, это не значит, что для экологии человека и социальной экологии философия не имеет никакого значения и не оказывает на них никакого влияния. Мы имеем в виду то, что в глобально-экологических исследованиях философия участвует (или должна участвовать) непосредственно, а не опосредствованно, как это имеет место в случае экологии человека и социальной экологии. Ведь глобальная экология должна стать (или быть) общетеоретической базой и непосредственным мировоззренческим основанием для этих разделов экологии как науки. 
Знание, вырабатываемое в экологии человека и в социальной экологии (если ограничиться ими и оставить в стороне глобальную экологию), действительно должно обладать своей спецификой. Оно не может быть сведено ни к естественнонаучному, ни к гуманитарному, ни к техническому знанию. Ведь естественнонаучное знание имеет своим содержанием информацию о естественных явлениях и процессах и тех закономерностях, которым они подчиняются. Гуманитарное знание - это знание, в котором отражено социо-культурное содержание, его аспекты и закономерности. Техническое знание - это уже особое знание. В.В. Чешев пишет [2, с. 269-270]: «При рассмотрении сущности технического знания возможны две крайности. Одна из них состоит в том, что технические науки принимаются за прикладное знание, не имеющее своих специфических познавательных задач и средств их решения. Другая крайность проявляется в отрицании научного характера технического знания. В последнем случае выделяют прикладные и фундаментальные науки, которым противостоит технология как набор предписаний и технологических рецептов».

Обратимся теперь к рассуждениям А. Н. Кочергина, Ю.Г. Маркова и Н.Г. Васильева, согласно которым в социальной экологии «участвуют естественные, общественные и технические дисциплины» на правах междисциплинарного взаимодействия наук. Ю.Г. Марков в одной из своих публикаций пишет: «Уникальность ситуации состоит в том, что в рамках социальной экологии приходят во взаимодействие практически все известные нам отрасли знания» [3, с. 225]. Возникает вполне оправданный вопрос: каким образомосуществляется согласованность такого взаимодействия? Ю.Г. Марков предлагает принцип кооперации: в системе кооперации выделяются поставщики, разрабатывающие различные детали или блоки, и головное предприятие, в котором осуществляется сборка целого. «Подобная ситуация, - пишет он [3, с. 227-228], - имеет место и при исследовании проблем социальной экологии. Здесь в роли целевого продукта выступает социально-экологическое знание (знание о наиболее рациональных взаимоотношениях между обществом и природой), а в роли предприятий-поставщиков - различные научные дисциплины, продуцирующие отдельные элементы знания, необходимые для “сборки” (синтеза) целевого продукта.

В рамках социальной экологии, выступающей в роли “головного предприятия”, - продолжает Ю.Г. Марков, - применяются различные технологии “сборки”. Основные из них три: 1) объединение (синтез) различных элементов дисциплинарного знания при помощи математических моделей (например, моделей оптимизации, имитационных моделей и т.д.); 2) организация специальных процедур синтеза информации, получаемых с экспертов - представителей различных отраслей знания; 3) кооперация научного знания путём организации проблемно-ориентированных исследовательских программ». 
Однако слова Ю.Г. Маркова на деле являются изображением не действительного, а желаемого положения дел. Синтез «различных элементов дисциплинарного знания» даже «при помощи математических моделей» возможен лишь применительно к естественнонаучным дисциплинам. Как известно, математизация социально-гуманитарных дисциплин до сих пор остаётся проблематичной. Синтез информации «различных отраслей знания» столь же проблематичен. Что касается третьего варианта «сборки», опирающейся на организацию «проблемно-ориентированных исследовательских программ», то об этом следует сказать следующее. Ещё в первой половине XX в. В.И. Вернадский отмечал [4, с. 67], что «рост научного знания XX в. быстро стирает грани между отдельными науками. Мы всё больше специализируемся не по наукам, а попроблемам. Это позволяет, с одной стороны, чрезвычайно углубляться в изучаемое явление, а с другой - расширять охват его со всех точек зрения». Это объясняется тем что проблема не может быть охвачена отдельной дисциплиной: её решение требует выхода за дисциплинарные границы. Между тем наука продолжает существовать в дисциплинарной форме - как множество различных дисциплин. Процессы интеграции и дифференциации, протекающие в современной науке, оставляют неприкосновенной её дисциплинарную организацию. Как реакция на это возникли междисциплинарные и комплексные исследования.

В то же время, как отмечает А.А. Хамидов [5, с. 413], «современные формы и случаи междисциплинарных исследований или комплексных подходов к решению тех или иных проблем ещё во многом находятся в плену у старого (дисциплинарного и функционального) разделения наук... Получается примерно такая картина. Вокруг целостной и многомерной проблемы собираются дисциплины-монады (часто поистине без окон, без дверей друг для друга), и каждая либо прилагает собственный конечный масштаб к проблеме, редуцируя её полноту к собственному уровню, либо же выхватывает из неё “кусок” содержания, помещающийся на её прокрустовом ложе концептуализации».

Процитированные слова полностью применимы к тем междисциплинарным и комплексным исследованиям, которые, согласно Ю.Г. Маркову и его единомышленникам, должны составить кооперацию во главе с социальной экологией. А ведь у него, А.Н. Кочергина и Н.Г. Васильева речь идёт ни больше, ни меньше, как об участии (кооперации) естественных, общественных и технических наук. Некоторые авторы ограничиваются только естественными и общественными науками. При этом многие исследователи области экологии человека и социальной экологии опираются на положение К. Маркса о так называемой «единой науке». В «Экономическо-философских рукописях 1844 года» К. Маркс писал [6, с. 124]: «Впоследствии естествознание включит в себя науку о человеке в такой же мере, в какой наука о человеке включит себя естествознание: это будет одна наука». Но, 
во-первых, сам Маркс не разъясняет ни того, как будет выглядеть эта наука, ни того, каким образом она сможет сформироваться. Во-вторых, в дальнейшем он больше ничего подобного не утверждал. Не вдаваясь в анализ Марксова высказывания, отметим, что единая наука на нынешнее время - это не реальность, а в лучшем случае идеал. В этой связи попытка представителей экологии человека и социальной экологии представить эти науки как достижение Марксова идеала выглядит несостоятельной.

В статье «Формирование социально-экологического знания», написанной Ю.Г. Марковым совместно с А.Н. Кочергиным и опубликованной тремя годами раньше цитировавшейся выше статьи Ю.Г. Маркова «Кооперативное взаимодействие наук в социальной экологии», позиция выглядит менее радикальной. А.Н. Кочергин и Ю.Г. Марков пишут [7, с. 212]: «Экологическое знание - особый феномен. Его элементы рождаются в различных отраслях знания, они ещё не экологическое знание в собственном смысле слова. Для этого нужен синтез, объединение в систему этих элементов. Знание становится экологическим лишь тогда, когда оно способно отразить общую цепь явлений антропогенного изменения природной среды и разработать программу сохранения и целенаправленного её улучшения.

Иными словами, - уточняют авторы,- экологическое знание целостно». Последнее замечание лишено смысла: если знание нецелостно, его вряд ли можно назвать действительным знанием. В то же время обращает на себя внимание то, что А.Н. Кочергин и Ю.Г. Марков говорят о социально-экологическом знании (целостном знании) как о действительно существующем феномене. А если это так, то следует говорить не о формировании социальной экологии (как и экологии человека), а об уже сформировавшейся научной дисциплине. В действительности же, дело обстоит далеко не так. Обе эти экологические дисциплины пока ещё находятся в стадии своего формирования. Но значит ли это, что до сих пор не существует экологического знания? Разумеется, нет. Оно, безусловно, существует, но существует ещё далеко не в той идеальной форме, как это представляется А.Н. Кочергину и Ю.Г. Маркову. Тем не менее обратимся к их трактовке специфики экологического (социально-экологического) знания.

В отличие от последующей точки зрения Ю.Г. Маркова, согласно которой в социальной экологии «кооперативно» взаимодействуют различные науки, в вышеназванной (и более ранней) совместной статье говорится [3, c. 212] о том, что преодоление «междисциплинарных барьеров в сложившейся структуре научного знания столь же проблематично, как и построение общей теории систем, которая со времён Берталанфи остаётся пока недостижимым идеалом». Необходимо, пишут они, переориентироваться на функциональный подход. «При функциональном подходе, - утверждают они [7, с. 213], - экологическое знание не сводится к тем или иным частностям дисциплинарного знания. Эколог, например, может вообще не вни- 
кать в тонкости физико-химических процессов, происходящих в природе в результате техногенных выбросов, но он обязан знать (в терминах, с помощью которых он определяет качество среды), куда развивается система и предвидеть угрозы её нормальному функционированию. Другими словами, экологу важно знать зависимость функционирования системы от значения её входных параметров». За функциональный подход ратует Ю.Г. Марков вместе с А.Н. Кочергиным и Н.Г. Васильевым в их совместной монографии «Экологическое знание и сознание. Особенности формирования» (1987 г.). А уже в 1988 г. К.Г. Марков выдвигает рассматривавшуюся выше идею кооперации наук в составе социальной экологии. Нам представляется, что данная идея менее перспективна, чем трактовка специфики социально-экологического знания с позиций функционального подхода.

Некоторые авторы (особенно географы), отмечают А.Н. Кочергин, Ю.Г. Марков и Н.Г. Васильев, отказываются признать фундаментальность экологического знания. При этом они опираются на традицию, в соответствии с которой фундаментальным считается только теоретическое знание. В экологическом же знании тесно сближаются теоретический и прикладной аспекты. И если, отмечают авторы, не принимать за критерий фундаментальности фундаментальность естественнонаучного знания, то экологическое знание следует признать фундаментальным. В то же время следует отметить, что ни экология человека, ни социальная экология не выходят на мировоззренческий уровень. На такой уровень выходит только глобальная экология. Но и только выходит, а не представляет собой уже такой уровень.

Итак, экологическое знание как специфическая форма научного знания существует, хотя способ его существования ещё очень далёк от того идеала, который некоторые исследователи некритически выдают за уже свершившееся явление. Поскольку, отмечают А.Н. Кочергин, Ю.Г. Марков и Н.Г. Васильев, «социальная экология является не только и не столько наукой о природных комплексах и происходящих в них под давлением антропогенных факторов изменениях, сколько наукой о человеческой деятельности, направленной на сохранение и дальнейшее развитие этих природных комплексов», постольку: «Окружающая среда с позиции эколога выступает не просто как совокупность различных природных объектов, подверженных антропогенному воздействию, а как компонент системы “общество - природа”. Тем самым в это понятие вносится момент социальной оценки» $[1$, c. 62]. Так мы подходим к вопросу о ценностных аспектах экологического знания. Но данный вопрос - лишь часть, или аспект, общего вопроса о ценностных аспектах науки и научного знания как таковых. Поэтому к нему и следует обратиться. 


\section{Проблема научных ценностей}

Однако сначала надо принять определенную трактовку ценностей, так как единого понимания в этом вопросе нет. Мы принимаем точку зрения Г.С. Батищева. Он выделяет в бытии человека «следующие три поля:

а) поле полезностей, которому соответствует наделённое самостоятельностью поле субъект-объектных отношений и логикаоконечивания;

б) поле устремлённостей, в котором объектные отношения снимаются более конкретнымимеждусубъектными, раскрытыми в беспредельность;

в) поле созидания самих бесконечных устремлённостей, или собственно творчества как космического универсального, бытийственного соавторствования» [8, с. 433]. Эти «поля» соотносятся иерархически: низшим является поле полезностей, более высоким - «поле устремлённостей», высшим - «поле созидания». Устремлённость имеет вектор. Это - ориентация на некие ценности (идеалы, святыни и т. д.). «В поле бесконечных устремлённостей, - пишет Батищев, - субъект выступает как такой субъект, для которого даже самая огромная величина полезностей не имеет силы влияния на него сравнительно с ценностным и целевым...» [8, с. 433] Следовательно, полезность связана с потребностью, а ценность - с устремлённостью. «В свете данного положения, - отмечает А.А. Хамидов, - ценность выглядит как объективный над-полезностный феномен, нередуцируемый к полезности и невывводимый из неё» [9, с. 191].

Обратимся теперь к проблеме научных ценностей. В позитивистской философии науки научное знание изображалось как ценностно нейтральное. Между тем, как показали М.К. Петров и Л.М. Косарева, этот «идеал ценностной нейтральности складывается в методологии науки в определённых социальных условиях функционирования науки» [10, с. 205]. Они делают вывод: «Образ ценностно нейтрального научного знания возникает как результат сознательных и организованных усилий деятелей, стремившихся содействовать развитию науки в период роста её специализации, профессионализации» [10, с. 229]. Ученые созданием этого образа стремились оградить науку от вмешательства в неё со стороны различных сфер социума. Позитивизм принял этот образ «за чистую монету» и стал отстаивать тезис о ценностной нейтральности научного знания. Но в XX в. этот образ стал уже препятствием в развитии науки.

На самом же деле наука никогда не была лишена ценностных аспектов, а научное знание всегда было ценностно нагруженным. Как отмечает X. Лэйси, идея науки, свободной от ценностей, базируется на понятиях беспристрастности, нейтральности и автономности (см.: [11, с. 40]). Проанализировав эти понятия, X. Лэйси заключает: «беспристрастность может и должна быть поддержана как жизненно важный тезис; нейтральность, несмотря на все двусмысленности, которые затрудняют её поддержку в чёткой 
форме, можно отстоять; лишь отдельные фрагменты автономности могут быть поддержаны» [11, с. 294]. На вопрос: свободна ли наука от ценностей, он отвечает отрицательно.

В.Ж. Келле обращает внимание на следующую особенность. «Когда говорится о концепциях ценностно-нейтрального научного знания, то имеются в виду соответствующие интерпретации его природы, процессы его получения, но не его практическое использование. Последнее всегда считалось ценностно нагруженным. И в основном оно рассматривалось как имеющее положительное значение для человека и общества» [12, с. 14]. Правда, тут необходима следующая оговорка. Процитированные слова в большей мере относятся к естественнонаучному и техническому знанию. Что касается знания, вырабатываемого общественными науками, то к нему со стороны общества, особенно авторитарного или тоталитарного типа, отношение было не всегда положительным. Общественные науки в условиях таких режимов находятся под мощным прессом официальной идеологии. Эта идеология стоит на защите интересов режима и потому налагает запрет на объективное знание, освещающее тайны этого режима. Такое знание для режима обладает отрицательной ценностью.

Приведём теперь и проанализируем ряд точек зрения на вопрос о соотношении науки и ценностей. Польский исследователь С. Амстердамский считает (цит. по: [13, с. 16]), что «вычленить здесь можно, как кажется, три круга проблем: во- первых, вопрос ценностей в науке. В его рамках находятся такие проблемы, как место ценностных суждений в содержании научных теорий, роль систем ценностей в познавательной деятельности учёного, проблема этоса науки, т.е. совокупности ценностей и вытекающих из них норм, на которые опирается функционирование науки как социального института. Во-вторых, вопрос иенностей для науки, значит системы ценностей, общественное признание которой вне науки является условием научного творчества. Иначе говоря, речь идёт о влиянии функционирующих систем ценностей в обществе на развитие науки, на изменение её внутренней структуры, а также на возможные изменения в её этосе... В-третьих, наконец, - вопрос ценностей науки, т.е. проблема ценностно-творческих и ценностно-разрушающих функций науки в общественной жизни, стало быть обратной зависимости, чем та, о которой мы упомянули в предыдущем пункте».

С. Амстердамский, таким образом, выделяет внутринаучные ценности и ценности за пределами науки, в социуме. При этом одна группа последних воздействует на науку, а другая представляет собой воздействие науки на общество, взятое в ценностном аспекте. В. Пуликовский, процитировавший вышеприведённые слова С. Амстердамского, выделяет не три, а пять видов взаимоотношения науки и ценностей. К трём, выделенным С. Амстердамским, он добавляет следующие: «4. Ценность как объект научно- 
го изучения... 5. Наука как элемент ценностных систем» [13, с. 22]. Нам представляется, что данное добавление не намного конкретизирует модель С. Амстердамского. Обратимся ещё к точке зрения Э. Агацци. Он формулирует [14, с. 107 - 108] следующие тезисы:

«А. 1. Всякое собственно человеческое действие ориентировано на ценности и руководствуется нормами;

А. 2. ценности и нормы различны;

А 3. ни одна наука, предметом которой является человек, не может не интересоваться также ценностями и нормами.

Б. 1. Всякая наука “свободна от ценностей”, если иметь в виду непознавательные ценности;

Б. 2. это обобщение распространяется и на гуманитарные пауки;

Б. 3. однако эти науки не могут не принимать во внимание нормы и ценности, признаваемые объектами их исследования, и не могут рассматривать их как чисто методологические “точки зрения".

В. 1. Несмотря на всё это, гуманитарные науки не выражают ценностные суждения и не устанавливают предписываюшие нормы в строгом смысле слова;

В. 2. поэтому в поисках таких суждений и предписаний они обращаются кдругого рода исследованиям. Здесь открывается собственно этический горизонт как форма исследования, отличного от всякого научного исследования».

Если сопоставить позиции С. Амстердамского - В. Пуликовского и Э. Агации, то, на наш взгляд, выигрывает первая. Наука, в том числе и гуманитарная, свободна, согласно Э. Агацци, от непознавательных ценностей. В том числе и от этических, о чём у него речь идёт в тезисе «Б. 2». Это - чисто объективистская точка зрения. Поэтому мы предпочитаем ей точку зрения С. Амстердамского, а от дополнений к ней В. Пуликовского можно, на наш взгляд, отвлечься как от несущественных.

Для науки, конечно, важны в первую очередь её собственные, внутренние ценности. Одной из высших таких ценностей является само научное знание, ради открытия и накопления которого и существует паука. Считаем необходимым подчеркнуть, что знание - это не только вненаучная ценность, ценность для общества и культуры, это также ценность и для самой пауки. Ведь знание внутри науки не складируется мёртвым грузом, а обращается в ней, становясь предпосылкой и условием получения нового знания. Высшей ценностью, разумеется, обладает истинное знание (истина - это одна из непререкаемых ценностей). Но и знание неистинное, ошибочное, даже заблуждение тоже является ценностью, так как по-своему стимулирует дальнейшие поиски истины. Заблуждение по-своему поучительно; поэтому в истории науки заблуждения, особенно, так сказать, великие (как, например, учение о флогистоне, теплороде и им подобные) играют весьма положительную роль. 


\section{Проблема ценностей экологического знания}

Обратимся теперь к экологии и к экологическому знанию. Знание, вырабатываемое биологической экологией, есть естественнонаучное знание и оно обладает в принципе той же общественной ценностью, как и всякое естественно-научное знание. Поэтому его можно оставить в стороне. Куда важнее обратиться к ценностным аспектам того знания, которое вырабатываютсверхбиологические варианты экологии - экология человека, социальная экология и глобальная экология. Глобальная экология носит общетеоретический характер, она не имеет прикладных вариантов. Она также всецело гуманитарная дисциплина. Знания, получаемые в ней, носят фундаментальный характер. Следует оговориться, что мы говорим скорее об идеале глобальной экологии.а вовсе не о том состоянии, в каком она находится. При этом, подавляющее число работ по глобально-экологической проблематике проводят антропоцентристскую мировоззренческую установку. Следовательно, по большому счёту, то знание, которое содержится в этих работах, не может считаться всецело положительным, отвечающим тем требованиям, которые предъявляет современному человечеству экологически ситуация. Авторы этих работ оперируют понятием ноосферы, но разве соответствует разуму («ноосу») забота этих авторов только о благе человека и общества? Так, казахстанский ученый С.Т. Тлеубергенов претендует на создание нового варианта экологии, которую он назвал нооэкологией. Он пишет [15, с. 29]: «Под нооэкологией автор понимает биосферу с разумным человеком, которая должна прийти на смену биоэкологии, сфере разумной жизни... Нам представляется, что перейти от биоэкологии можно только в том случае, если мы от природоохранительной экологии перейдём к сознательной, разумной, мыслительной, нравственной человеческой экологии -нооэкологии».Но если нооэкология - это всего лишь «биосфера с разумным человеком», то не синоним ли это ноосферы? Ведь, согласно В.И. Вернадскому, именно благодаря разумной деятельности человека биосфера на определённом этапе начала переходить в ноосферу. А если это так, то к чему тогда новый термин, хотя он и звучит красиво? Кроме того, обращает на себя внимание, что автор несколько неопределённо трактует понятие «биоэкология», ставя знак равенства между ним и понятием «сфера разумной жизни». Ведь биоэкология - это не что иное, как биологическая экология, раздел науки биологии. А тогда при чём тут «сфера разумной жизни»? В итоге выясняется, что нооэкология для С.Т. Тлеубергенова это та же экология человека.

Экология человека и социальная экология, в отличие от глобальной экологии, имеют и теоретический, и прикладной уровни. В этих дисциплинах, видимо, в большей степени, чем в других, взаимосвязаны их теоретические и прикладные аспекты. Вырабатываемое здесь знание непосредственно 
ориентировано на его практическое применение. Как отмечают А.П. Кочергин, Ю.Г. Марков и Н.Г. Васильев [1, с. 26], в социальной экологии «положение таково: вне процессов принятия и практической реализации решений никаких теоретических обобщений сделать невозможно. И экологическое знание существует лишь постольку, поскольку оно направлено на непосредственное решение практических проблем». Следовательно, можно сказать, что в экологическом знании (имеются в виду знания, получаемые экологией человека и социальной экологии) неразрывно соединены знания-описания и знания-предписания.

В экологии человека и в социальной экологии действует та же система внутринаучных ценностей, что и во всякой другой научной дисциплине. Однако имеется и собственная специфика. В естественных, технических и даже в общественных науках понятия, будучи сами по себе ценностями, в самих себе не содержат оценок. Скажем, понятия электрона, массы, скорости и т.д. в физике, вида, биоценоза, хромосомы и т.д. в биологии, товара, прибыли, конкуренции и т.д. в политической экономии не содержат в себе оценки тех реальностей, которые они отражают. Причём они не содержат её как во внутринаучном пространстве, так и во вненаучном, в социокультурном контексте. С некоторыми экологическими понятиями дело обстоит принципиально иначе.

А.Н. Корчагин, Ю.Г. Марков и Н.Г. Васильев пишут [1, с. 62]: «Окружающая среда с позиции эколога выступает не просто как совокупность различных природных объектов, подверженных антропогенному воздействию, а как компонент системы “общество - природа". Тем самым в это понятие вносится момент социальной оценки. Это видно уже из того, что состояние окружающей среды связывается с понятием её качества. Вне социальных оценок всякая среда не будет ни хорошей, ни плохой, она будет просто объектом, противостоящим человеческому сознанию и отображаемым этим сознанием подобно другим физическим телам». Причём эта ценностная нагруженность экологических понятий является таковой не только для социокультурной действительности, но и для самой науки - экологии человека и социальной экологии.

Вместе с тем, на наш взгляд, следует различать абсолютную и относительную ценность экологического знания (это относится к знанию вырабатываемому экологией человека, социальной экологией и глобальной экологией). Особенно это значимо для современных условий, когда угроза экологического кризиса представляется как никогда реальной. Абсолютная ценность экологического знания - это ценность его как такового. В нынешней экологической ситуации оно абсолютно необходимо, ибо без него невозможно человечеству справиться с этой ситуацией. Оно поэтому и обладает статусом абсолютной ценности для человечества.

Но знание, как известно, есть не только результат познания, но и процесс. Всякое наличное знание конкретно в диалектическом смысле, т.е. содержит в себе не только истину, но и определённую долю неистинности. 
Последующее развитие познания устранит какие-то элементы неистинности, незнания, но какие-то сохранит, а какие-то ещё и прибавит. Такова вообще логика человеческого познания. Знание всегда относительно, экологическое знание в том числе. Поэтому ценность конкретного экологического знания всякий раз относительна.

\section{Заключение}

В статье, во-первых, более строго подчёркивается разграничение биологической экологии от экологии человека, социальной экологии и глобальной экологии. Эти дисциплины несводимы не только к естественным и техническим, но и к обычным социогуманитарным дисциплинам. Во-вторых, показано, что исследователи часто выдают желаемое за действительное, описывая применение комплексных исследований к вышеназванным экологическим дисциплинам. В-третьих, отмечается антропо-центристская установка большинства исследователей в области экологии человека, социальной и глобальной экологии. В-четвёртых, проведено различение абсолютных и относительных ценностей экологического знания применительно к вышеназванным дисциплинам.

В качестве возможных перспектив дальнейшего исследования проблем, затронутых в статье, следует отметить, прежде всего, необходимость радикального перехода экологических исследований на неантропоцентристские позиции, что значительно повысит ценность экологических знаний.

\section{Список литературь}

1. Кочергин А.Н., Марков Ю.Г., Васильев Н.Г. Экологическое знание и сознание: особенности формирования. - Новосибирск: Наука, 1987. - 221 с.

2. Чешев В.В. Технические знания и взаимосвязь естественных, общественных и технических наук // Методологические проблемы взаимодействия общественных, естественных и технических наук. - М.: Наука, 1981. - С. 269 - 287.

3. Марков Ю.Г. Кооперативное взаимодействие наук в социальной экологии // Взаимодействие наук как фактор их развития. - Новосибирск: Наука, 1991. - С. 225 - 243.

4. Вернадский В.И. Научная мысль как планетное явление. - М.: Наука, 1991. $-271 \mathrm{c}$.

5. Хамидов А.А. Перспективы развития науки // Логико-гносеологический анализ науки - Алма-Ата: Гылым, 1990. - С. 362 - 424.

6. Маркс К. Экономическо-философские рукописи 1844 года // Маркс К., Энгельс Ф. Сочинения. - Изд. 2-е. - М.: Политиздат, 1974. - Т. 42. - С. 41 - 174.

7. Кочергин А.Н., Марков Ю.Г. Формирование социально-экологического знания // Проблемы методологии науки. - Новосибирск: Наука, 1985. - С. 208 - 221.

8. Батищев Г.С. Диалектика как логика мировоззрения целостно развитого человека, как логика его творческого отношения к миру и к самому себе: перспекти- 
вы // Батищев Г.С. Избранные произведения. - Алматы: ИФПР КН МОН РК, 2015. - C. $426-434$.

9. Хамидов А.А. Гуманизм как дискурс. - Алматы: ИФПР КН МОН РК, 2012. $-212 \mathrm{c}$.

10. Петров М.К., Косарева Л.М. Формирование идеала ценностно нейтрального знания. (Аналитический обзор) // Социокультурные факторы развития науки (по материалам историко-научных исследований). Сборник научно-аналитических обзоров. - М.: ИНИОН АН СССР, 1987. - С. 205 - 232.

11. Лейси Х. Свободна ли наука от ценностей? Ценности и научное познание. - М.: Логос, 2001. - 359 с.

12. Келле В.Ж. Научное познание и ценности гуманизма // Ценностные аспекты развития науки. - М.: Наука, 1990. - С. 7 - 18.

13. Пуликовский В. Современная наука и ценности // Ценностные аспекты науки и проблемы экологии. - М.: Наука, 1981. - С. 9 - 23.

14. Агацци Э. Моральное измерение науки и техники. - М.: Московский философский фонд, 1998. - 344 с.

15. Тлеубергенов С.Т. Нооэкология. - Алматы: Гылым, 1996. - 115 с.

\section{Transliteration}

1. Kochergin A.N., Markov Ju.G., Vasil'ev N.G. Jekologicheskoe znanie i soznanie: osobennosti formirovanija [Ecological knowledge and consciousness: features of formation]. - Novosibirsk: Nauka, 1987. - 221 s. (in Russ).

2. Cheshev V.V. Tehnicheskie znanija i vzaimosvjaz' estestvennyh, obshhestvennyh i tehnicheskih nauk [Technical knowledge and the relationship of natural, social and technical sciences] // Metodologicheskie problemy vzaimodejstvija obshhestvennyh, estestvennyh i tehnicheskih nauk. - M.: Nauka, 1981. - S. 269 - 287. (in Russ).

3. Markov Ju.G. Kooperativnoe vzaimodejstvie nauk $v$ social'noj jekologii [Cooperative interaction of sciences in social ecology] // Vzaimodejstvie nauk kak faktor ih razvitija. - Novosibirsk: Nauka, 1991. - S. 225 - 243. (in Russ).

4. Vernadskij V.I. Nauchnaja mysl' kak planetnoe javlenie [Scientific thought as a planetary phenomenon]. - M.: Nauka, 1991. - $271 \mathrm{~s}$.

5. Hamidov A.A. Perspektivy razvitija nauki [Prospects for the development of science] // Logiko-gnoseologicheskij analiz nauki. - Alma-Ata: Gylym, 1990. - S. 362 - 424. (in Russ).

6. Marks K. Jekonomichesko-filosofskie rukopisi 1844 goda [Economic and philosophical manuscripts of 1844] // Marks K., Jengel's F.Sochinenija. - Izd. 2-e. - M.: Politizdat, 1974. - T. 42. - S. 41 - 174. (in Russ).

7. Kochergin A.N., Markov Ju.G. Formirovanie social'no-jekologicheskogo znanija [Formation of socio-ecological knowledge] // Problemy metodologii nauki. Novosibirsk: Nauka, 1985. - S. 208 - 221. (in Russ).

8. Batishhev G.S. Dialektika kak logika mirovozzrenija celostno razvitogo cheloveka, kak logika ego tvorcheskogo otnoshenija k miru i k samomu sebe: perspektivy [Dialectics as the logic of the worldview of a holistically developed person, as the logic of his 
creative attitude to the world and to himself: perspectives] // Batishhev G. S.Izbrannye proizvedenija. - Almaty: IFPR KN MON RK, 2015. - S. 426 - 434. (in Russ)

9. Hamidov A.A. Gumanizm kak diskurs [Humanism as a discourse]. - Almaty: IFPR KN MON RK, 2012. - 212 s. (in Russ).

10. Petrov M.K., Kosareva L.M. Formirovanie ideala cennostno nejtral'nogo znanija. (Analiticheskij obzor) [Formation of the ideal of value-neutral knowledge. (Analytical review)] // Sociokul'turnye faktory razvitija nauki (po materialam istoriko-nauchnyh issledovanij).Sbornik nauchno-analiticheskih obzorov. - M.: INION AN SSSR, 1987.S. 205 - 232. (in Russ).

11. Lejsi H. Svobodna li nauka ot cennostej? Cennosti i nauchnoe poznanie [Is science free of values? Values and scientific knowledge]. - M.: Logos, 2001. - 359 s. (in Russ).

12. Kelle V.Zh. Nauchnoe poznanie i cennosti gumanizma [Scientific knowledge and the values of humanism] // Cennostnye aspekty razvitija nauki. - M.: Nauka, 1990. -S. 7 - 18. (in Russ).

13. Pulikovskij V. Sovremennaja nauka i cennosti [Modern science and values] // Cennostnye aspekty nauki i problemy jekologii. - M.: Nauka, 1981. - S. 9 - 23. (in Russ).

14. Agacci Je. Moral'noe izmerenie nauki i tehniki [The moral dimension of science and technology]. -M.: Moskovskij filosofskij fond, 1998. - 344 s. (in Russ).

15. Tleubergenov S.T. Noojekologija [Nooecology]. - Almaty: Gylym, 1996. - 115 s. (in Russ).

\section{СВЕДЕНИЯ ОБ АВТОРЕ}

\begin{tabular}{|l|l|}
\hline Ардак Рамазановна Айтбаева & $\begin{array}{l}\text { доцент, кандидат философских наук, профессор, } \\
\text { Пограничная академия КНБ Республики Казахстан, } \\
\text { Алматыл }\end{array}$ \\
\hline Ардақ Рамазанқызы Айтбаева & $\begin{array}{l}\text { доцент, философия выльмлдарының кандидаты, } \\
\text { профессор, Қазақстан Республикасы ҰҚК Шекара } \\
\text { академиясы, Aлматы }\end{array}$ \\
\hline Ardak Aitbayeva & $\begin{array}{l}\text { associate professor, candidate of philosophical sciences, } \\
\text { professor, Border academy of National Security } \\
\text { Committee of the Republic of Kazakhstan, Almaty }\end{array}$ \\
\hline
\end{tabular}

Ссылки на данную статью: Айтбаева А.Р. Ценностные аспекты экологического знания // Адам әлемі. - 2021. №1 (87), сc. 17-32. 